\title{
Modern Challenges of Human Resource Management Practice in Job Placement and Recruitment Within Organisations in the African Continent
}

\author{
Abdul-Kahar Adam ${ }^{1,2}$ \\ ${ }^{1}$ Department of Human Resource Management, University of Education, Winneba, School of Business, Winneba, Central Region, Ghana \\ ${ }^{2}$ Azman Hashim International Business School, Universiti Teknologi Malaysia (UTM), Skudai, Johor Bahru, Malaysia
}

Email address:

akadam@uew.edu.gh, Aabdulkahar2@graduate.utm.my

\section{To cite this article:}

Abdul-Kahar Adam. Modern Challenges of Human Resource Management Practice in Job Placement and Recruitment Within Organisations in the African Continent. Journal of Human Resource Management. Special Issue: Modern Challenges of Human Resource Management Practice in Job Placement and Recruitment within Organisations. Vol. 8, No. 2, 2020, pp. 69-75. doi: 10.11648/j.jhrm.201200802.14

Received: February 19, 2020; Accepted: March 6, 2020; Published: April 1, 2020

\begin{abstract}
The practice and implementation of Human Resource Management process has become under crossroad with other professions within an organisational structures. The roles of accountants, finance officers, auditors, registrars, and most directors are often seen in performing the responsibilities and functions of Human Resource Manager. Hence, the intriguing fact is that most Human Resource Managers are not well placed within the organizational structures. Besides, the placement and recruitment of HRM potentially professionals are limited within the organizational structure which creates more difficulties for the Human Resource Management discipline going forward. Hence, the purpose of this research is to theoretically discuss these challenges to ascertain recommendations that will follow this study. Several studies have shown how HRM is misapplied in certain institutions and sectors and that disrupts the general purpose of the profession. Another challenge that needs to be checked is the eminent diminishing of potential students and trainees in this sector due to lack of available jobs to equate the number of graduates from this sector discipline. The question that kept coming up is who is responsible for recruitment management and administration of staff? Is it the line managers in the various departments and other sectors or the HRM unit? If it is the HRM unit how is it the HRM duty and responsibility, especially when it comes to specialization of staffing issues? This study is a theoretical applied study of research based on constitutions, laws, polices and theoretical studies. It is important to cross examine how HRM role and function are applied or placed within public sector organisations and institutions especially, within the institutions of higher learning-universities structures. This of course may vary from country to country where such conflict of misplaced profession needs to be clarified by standards of HRM profession. These research findings are based on secondary and theoretical sources of data.
\end{abstract}

Keywords: Job Placement, Recruitment, Organisational Structure, Roles and Functions of HRM, Definition of HRM, HRM

\section{Introduction}

A research revealed that the citizens of Nigeria are mostly employed into administrative roles whereas the foreigners are employed as technical staff within one company surveyed [1]. The research also concluded the process and procedure used in recruiting Nigerians are quite different to that of nonNigerians (foreigners or white people or Chinese). And in this research, it further noted that there is discrimination against the nationals of Nigeria since the foreigners who are employed as technical staff receives better conditions of service and treatment than the Nigerian counterparts. It recommended the need for technical know-how to the indigenes by the efforts of the companies they work with. The essence of this research is to point out the flaws in Human Resource Management practice in line with job placement and recruitment. The overall meaning of Human Resource Management is to reduce human suffering at workplaces and then make them happy and comfortable. It does appear same cannot be said when it comes to an African country's practices of this new discipline in the $21^{\text {st }}$ century. Human Resource Management is the process of increasing 
skills, knowledge and capacity building of employees and the citizens at large in order to apply same for development [2]. There are various functions through which this HRM operates effectively and efficiently, and two of it are job placement and recruitment processes in order to curb the challenges.

Human Resource Management will always help organisations to achieve its objects by highly motivating its employees which in effect will increase productivity of the organization, also quality of products will be improved, time well managed and less over runs [3]. The research further submitted that HRM is a management tool used in a coherent manner as an organizational asset including the workforce. Thereby HRM simply deals with the process of developing, attracting and maintaining energetic and talented workforce towards achieving organisational objectives. This means that the success of an organization lies with the people it engaged to do the work or business since it is their performance that makes everything possible.

\subsection{Objectives}

The following are the main objectives of this research:

1. To establish the new trend of challenges affecting Human Resource Management Practice in the African continent.

2. To establish whether the term job placement is effective and still relevant in parts of African countries.

3. To determine the recruitment processes that are commonly used in organisations in African countries.

\subsection{Problems}

Human Resource Management study is a new discipline that is adopted into the continent for about a little over 30 years within the African continent. This is a fact because in around 1995 thereabout that the most institutions started introducing the term Human Resource Management when in fact Personnel Management materials where used to deliver this new discipline called Human Resource Management. From HRM origins, it means that many organisations and institutions started practicing HRM as a label since there was no trained professional then to handle the discipline thoroughly. But now since time past, what is the status of the HRM practice in the continent? Is it helping organisations and government to achieve development agendas? These are the main problems and challenge that need dissecting in this research. The basic problems of recruitment by organisations are that senior management priority is centered on low decision making, providing short term objectives rather than looking at the future $[4,5]$. Human Resource Management problems in a Nigeria firm as inefficiency in planning workforce, foreign language barriers, interference of political parties or government in the recruitment of staff, favouritism when it comes to promotion and appraisals, there is no seriousness in disciplinary actions, lack of compliance with regards to HRM recruitment principles are those major problems affecting many companies [1]. This is the more reason why it is important to research into the wider perspective to establish better conclusions and recommendations.

Some of the previous findings discussed as the challenges affecting the recruitment process includes lack of recruitment and selection plans, lack of good policies, technological changes of tools use, using old methods and systems of recruiting, lack of succession plans, lack of interview skills, lack of motivation and the physical challenges at the work environment [6]. In Africa, management practice through the importance of cultural values has become challenging since almost all the African organisations and institutions are established and operated the same way as the Western management have been created and the assumptions made in textbooks and the models are in fact, has not helped the Africans to achieve their economic expectations for sustainable growth and development [7]. That there are limited knowledge about the cultural values of Africans to be used in the management process and practice in their institutions but rather the adoption of the Westerner and American cultural practices and model assumptions in management disciplines.

More so, the Western management theories are not consistent with the values and traditions of Africans practice of management and its principles. A situation that calls for an African Management studies in line with their cultural and moral values is eminent. There is rapid transformation to the business landscapes which means that there are many human resource management challenges currently and it will continue to evolve for many years to come [8]. That human resource management departments must be adding more real business values in practice to their organisations. This in itself means that no condition is permanent, the function and objectives of HRM will continue to evolve and change according to trends of real cases and issues globally affecting business organisations. The business world changes the same way as Human Resource Managers and professionals' roles too changes. The following are the major top 10 Human Resource Management challenges namely change management in organisations, lack of leadership development, poor measurement of HR effectiveness, lack of organisational effectiveness, lack of good compensation systems, lack of availability of skilled labour locally for recruitment (poor staffing methods), lack of succession planning, lack of learning and development, poor retention plans, and lack of benefits like health and welfare maintenance. These are global HR management phenomenon.

\section{Literature Review}

It is important for managers to think globally and locally as well because they are some environmental factors which are problems in the adoption of international HRM to that of the local or continental HRM practices Chukwuma [1]. The following are the factors that affects Human Resource Management adoption in the African continent. These are Economic System, Legal System, Political System, 
Educational System, and Socio-cultural and Ethical Systems [9].

\subsection{Economic System}

There is always a way by which economic system in a country influences its application and adoption of Human Resource Management. This happens in a number of forms, for example it is suggested that there are always more opportunities in developing their human capital as well as their technical know-how since such a country educational system are almost free or catered by the government and this takes the form of socialist economic system. Whereas in the capitalist economic system, there are no many opportunities in developing their human capital or technical know-how and this is associated with high cost of resources to acquire knowledge and skills. This lay it bear for international firms to always make provisions in their investment operations in Africa compatible with training their workforce to acquire the necessary experience and qualifications required for them to reinvest their human capital developed for business investment growth.

\subsection{Legal System}

Every country has its own legal systems which in fact and at times is adapted or adopted from other international countries by African countries. Legal system affects Human Resource Management practice in the African continent since African countries are under developed and therefore still survive with aids from international superpowers. Therefore, many HRM factors and principles are constantly misapplied or malpractice at most against employees or company workforce. In Ghana for instance, there are many HRM issues that the unions have put before the National Labour Commission to come to their aid so that employers or the government will do the right things in fulfilling their grievances of their needs.

\subsection{Political System}

Politics is a democratic practice which is one of the reforms that was directed to African countries to strive to achieve and practice good governance. But this is a constant challenge in Africa since African countries politics is occupied by selfishness and greed. Besides, Africans mode of doing politics is different to the rest of the world. They are not been able to uphold to the legal rights of the constitution which at most is been abused and misused. Winner takes all politics has killed and still killing the moral fiber of their citizens in the test of integrity which is lacking. Therefore, the politics in Africa stampede any accurate HRM practice. At times appointments by most governments are done by political influence or by political party affiliation and not according to HRM recruitment processes.

\subsection{Educational System}

Education is key to any country development. It is an embodiment of what a country needs to move its country to the advance stage. Within the African continent education is still a struggle whereby many more are still developing their basic curricular to design the nature of education they want. Though majority of Business Schools at the university and tertiary level design HRM course but there are challenges when it comes to educational competition with other courses. Due to poor design of curricular at secondary school level without any subject or teachings of HRM at that level makes most HRM students to underperform against other students who had the foundations at the secondary school level of their major course. Example is like accounting, mathematics, and other technical course subjects. Hence, there are discrepancies in the design of school curricula's in most African Countries syllabus.

\subsection{Socio-Cultural and Ethical System}

This is the bedrock of integrity but such moral and cultural fabrics are been damaged by lack of patriotism. The love for countries is not what is built in Africans but the unethical means and ways of acquiring wealth. Many at times it appears Africans worship and praises wrong doings in their countries because democracy is what has been misunderstood and misapplied in the system. The use of power is more than diplomacy and at most not following the rule of law. Hence, the socio-cultural and ethical systems are broken and therefore lacks due diligence and integrity in doing business and investing in their own countries. Corruption in Africa is the order of the day and it has eating into any moral standards in their societies and therefore affects the practice of HRM within their economic settings. Most at times it is not your qualification or good behavior that will earn you your dream job but the irony.

A research findings showed that there is some due process been followed when conducting a recruitment process but ironically, the selection processes are usually mad with interference with competitive conditions of work [3]. That, the development of competences of employees' job-related works are not been paid much attention to that of orienting newly recruited staff on training and development. Many more of the challenges of HRM in the African continent are that there is interference of employees' recruitment, high labour turnover, lack of competitive salaries and wages, and compensation policies are not well practiced.

It is noted that African organisations can learn and adopt the best performing countries of Human Resource Management namely Singapore, New Zealand, United Kingdom, USA, Germany, etc in order for Africans to develop their capacities, innovation, and performance evaluation [10]. These advanced and developed countries with good and best human resource management practices has the following functions and characteristics that African countries and its governments can adopt and practice.

The developed nations HRM have performance based offer of contracts for senior officers in the public sectors, they focused on their citizen to deliver services and jobs, staff reward systems are linked to their performance capacities, they have established special schools for training 
and building the capacities of government workers and professionals to develop and build a culture for achieving good results in the public sector, the HRM values and its principles and objectives are enshrined in their laws for strict compliance and high standards of ethics professionally in the public sector services, they delegate duties and responsibilities as powers of the of the HRM directs at the lower and middle level public offices and to the ministries and departments to perform, and they have strong regulatory framework meaning that their commissions or equivalent title have transformed their roles to carry out the regulatory rather than the transactional functions that ensures value for money principles are adhered to within the human resource management scope.

Recruitment is defined as a process of gathering people who are qualified by responding to the advertisement and applied for the selection of the best applicant or candidate for the job [11]. The process of finding a highly qualified and attractive candidates to apply for job vacancy in an organization [12]. A process of recruiting a pool of competent applicants to apply for job vacancy in an organization [13]. Recruitment is the concern of an organization to generate a pool of qualified people to apply for job in an organization [14]. A set of activities and processes that are legally used to a get qualified people to apply for employment at the right time, right place, and right job for a combined understanding between the organisation and the applicant [15].

In other words, selection is part and parcel of the recruitment process and it means that a process of choosing applicants from a group who are deemed qualified and applied for employment in an organization [16]. Selection as the process of choosing the most suitable and qualified applicants [17]. A process by which specific instruments are used to select qualified individuals from a group of applicants for an available job vacancy [13]. Previous research findings argued that using a systematic selection process includes the process of recruiting, information gathering about qualified applicants, evaluation of the applicants qualified and finally making employment decision [18].

\subsection{Definitions of HRM}

Human Resource Management is defined HRM as a coherent approach to management and strategies of the valued assets of an organization namely the people working towards the attainment of organizational objectives [10]. And that to have effective HRM it must be operating through systems that follows: HRM programmes that support policies, strategies and the implementation practices by plans, Processing of formal procedures and methods, establishing values, strategies and principles for implementation, identifying directions of HRM, and managing people through guiding principles.

Moreover, the major aim of HRM is to ensuring that organizational goals are achieved by its people as workforce. Human Resource Management framework across African countries is embedded in the countries' constitution and Acts that establishes the institutions and regulations for the administration of people management in public institutions [10]. The main essence of this is that the established Commissions are sort of independent bodies with the sole responsibility for HRM within public institutions which intends to ensure public appointments and promotions principles are distinguished to that of civil servants' job protections from unlawful or unsuitable interference from politicians.

It is established that the practice of public service commissions began in the United Kingdom when the first Civil Service Commission was established around middle of $19^{\text {th }}$ century and [19] wrote that the civil service during that period was very scanty, hence recruitment was done mainly through patronage and also base on personal recommendations from top people. But over a time now it has become apparent since its been limited in operation when the industrial revolutions started, government tasks also expanded, electorates also broadened, the middle class started to require more open access to civil service jobs with better performance. As a result of these, the commissioners demanded people fitness which then brought competition in a form of examination as entrance requirement into the civil service whereas promotion was based on merit thereafter. It is also established that similar public service commission was established in Canada, Australia, and New Zealand in the later part of the $19^{\text {th }}$ and early $20^{\text {th }}$ Century and then also established in the other British colonies between 1950 and 1960.

\subsection{Limitation}

Due to the scope of this research topic, it has been thought through carefully before streamlining it to only existing sources of information that refers to African countries and data to enable its submissions clear and straight to the point. Hence, only researches that has human resource management challenges are those that are considered most for this research findings.

\section{Methodology}

This research paper is based on secondary and empirical sources. Therefore, it is considered as qualitative research where previous findings data are analyzed and made conclusion and recommendation. It is a non-probability study on facts that are already presented by various authors as appropriate and in this case the population was not chosen, hence qualitative and theoretical representations are been made.

\section{Findings from Available Literatures}

Findings showed that Human Resource Management practices such as recruitment, performance, compensation, training, reward systems, and appraisals are still in operational but there have been challenges of nepotism or 
tribalism, corruption, training and development [20]. These are the kind of difficulties confronting HRM within most Nigeria public institutions.

Also, Msiska, R. [10] argued that before African continent and the African Union will achieve its vision of Agenda 2063, a vision that will integrate peaceful and prosperous Africa, championing by Africans and have a representation in the international market place, would not be easy until some major challenges are rectified and curtailed as follows. That, no more politicization of public service appointments to positions, no more lack of customized public service employees competence based training and development, performance management systems are linked to the national mission, visions and developmental goals, there must be improvement in the poor culture, indiscipline, and motivating of employees by not just allowing only government commissions to keep wasting time to communicate within time bounds, the lack of good human resource management issues which the government CEOs and Ministries and departments are inadequate to display accountability in most fronts, the bureaucratic systems must be improved to prevent delays in the process of staff matters by the Commissions as it causes a lot of distractions and delays, and also, centralized decision making systems must be changed to a more robust and strategic human resource management process to discontinue the government ministries and departments not to be seen conducting transactions and recruiting personnel on their own.

The following are some of the African countries that shows how the level of human resource management are practiced in the public sector organizations [10] by adaption.

Table 1. Some good HRM written policies in Ghana, South Africa, Zambia, and Kenya.

\begin{tabular}{|c|c|c|c|}
\hline Ghana & South Africa & Zambia & Kenya \\
\hline $\begin{array}{l}\text { Ghana has a Public Service } \\
\text { Commission (PSC) which is } \\
\text { established under the constitution } \\
\text { with the main function to operate } \\
\text { independently. They are to regulate } \\
\text { and provide oversight duties in the } \\
\text { appointments of public officers and } \\
\text { other human resource management } \\
\text { functions and processes. They are } \\
\text { directly involved in appointment and } \\
\text { recruitment of chief directors, } \\
\text { directors, and deputy directors in the } \\
\text { public sector institutions with the } \\
\text { consultation of the governing } \\
\text { councils before those appointments } \\
\text { and recruitments. PSC has } \\
\text { established its human resource } \\
\text { management policy framework and } \\
\text { manual in order to achieve culture } \\
\text { based and merit and performance of } \\
\text { citizens through proper orientation. }\end{array}$ & $\begin{array}{l}\text { In South Africa their PSC } \\
\text { functions like a regulatory body } \\
\text { to empower by conducting } \\
\text { investigations, monitoring, and } \\
\text { evaluating organisations, } \\
\text { personnel practices and } \\
\text { administration of public offices. } \\
\text { They adhere to the values and } \\
\text { principles set out in their } \\
\text { constitution section } 195 \text { and } \\
\text { public office procedures. The } \\
\text { commissions primary objective } \\
\text { is to promote and establish } \\
\text { measures that would ensure } \\
\text { efficient and effective } \\
\text { performance within the public } \\
\text { sector through the promotion of } \\
\text { principles and values of public } \\
\text { administration as enshrined in } \\
\text { the constitution. }\end{array}$ & $\begin{array}{l}\text { In Zambia, there is a comprehensive } \\
\text { human resource management reforms } \\
\text { which aimed at restoring confidence in } \\
\text { the public sectors by strengthening } \\
\text { governance and other structures. They } \\
\text { introduced merit and progression base } \\
\text { system for appointments and } \\
\text { promotions to all public sector } \\
\text { organisations and rather delegates the } \\
\text { human resource functions to the lower } \\
\text { levels. It has adopted and implemented } \\
\text { a competitive integrated remuneration } \\
\text { strategy which seeks to achieve the } \\
\text { equal pay for equal work system and } \\
\text { principle over a } 10 \text { years' duration. } \\
\text { They have adopted a single spine } \\
\text { salary structure which brought a lot of } \\
\text { competition to the public sector in } \\
\text { terms of pay, hence attracting many } \\
\text { more talented workers from the } \\
\text { private sectors. }\end{array}$ & $\begin{array}{l}\text { Kenyan government has introduced } \\
\text { performance contracts in } \\
\text { management of the public Sectors } \\
\text { in } 2004 \text {. It is major objective is to } \\
\text { ease managers from unproductive } \\
\text { and uncoordinated activities in } \\
\text { order for them to focus on } \\
\text { important tasks. These performance } \\
\text { contracts are linked to the overall } \\
\text { National Vision } 2030 \text { including the } \\
\text { medium-term plan. It has improved } \\
\text { the innovation and culture base } \\
\text { results which in fact, Kenya School } \\
\text { of Government has played a major } \\
\text { role in protecting and promoting the } \\
\text { performance culture through } \\
\text { professional development are } \\
\text { sustained. }\end{array}$ \\
\hline
\end{tabular}

\section{Conclusion and Recommendation for Future Research}

From the research findings, it is clear that job placement in today modern Africa is very rare because there is very high unemployment rate of graduates and the skilled people. Hence, it does appear that no organization in today's HRM practice have a system or database of graduates who are looking for jobs and are placed in that database for future invitation. These days in Africa, before you hear a job vacancy it is generally perceived that the vacancy is already filled and so the advertisement is just fulfilling the recruitment process as an indication. Some of the countries in Africa practice a disjointed form of Human Resource Management since their laws does appear to be too stringent on personnel seeking for justice and redress but without equivalent human resource management principles as a body or organization to handle many employment issues without been referred to court or national commissions for solutions.
This is because HR Managers in Africa does not manage the regulation itself but rather made to transact them. This does mean that there is lack of true professionals of the Human Resource Management practice background which does not even support accordingly to the norms and practice of the profession of HRM.

The recruitment process on the other hand in Africa is mainly based on whom you know and who knows you. This is not like the professional practice of HRM where an employer may ask its staff to direct their relatives or friends whom they think have pre-requisite experience and qualification for a job vacancy which is internal advertisement. It is widely known locally that most governments appointments and employment of people into the public sector offices are not based on pre-requisite qualification and experience but rather political and relationship matters. The governments and politicians even prepare their own list for recruitments and given out to the department that is to recruit new personnel. In this case, HRM practice in the African continent is not really what 
people think of the professional standards and principles of HRM but rather based on a different kind of practice which does not actually increase productivity from employees but rather reduces growth of organisations. That is the more reason why organizational achievements of objectives in the African countries are very poor and low because the real practice of HRM has been short change to, too much power drunk and abuse of authority which undermines the existence of Human Resource Management. This does show that the practice of Human Resource Management in the African continent is a bane and also described as HRM by label. What is common in African countries in the practice of HRM is rather still the old Personnel Management where only pay, annual leave, and some sponsorship or scholarship for further studies are what concerns the governments. But, it must be pointed out that sponsorship for further studies is not training and development but an advancement of an individual educational level.

Therefore, it is obviously clear that policies, regulations, laws, and the constitution are all provisions and not in itself a success but they are just establishments, and if it is well managed it should achieve its objectives. Hence, public sector establishments and its functions need further investigations to ascertain whether those laws, regulations and policies governments create towards jobs creation and recruitment of personnel are really promoting good Human Resource Management practice or not? It must also find out whether the laws and policies, truly support the practice of professional HRM in their countries. In this case, a quantitative study of this kind is proposed. This is because the essence of the creation and establishment of HRM to replace the traditional personnel management globally is to reduce human suffering and this is not what we see in African countries. HRM practices are weak and everything is controlled by politics and political affiliations. The real benefits of Human Resource Management practice are missing in the African continent as a whole due to the lack of adaptation of their African values and culture into management studies and practice. This must change as appropriate by all African countries, that is, the way they design their courses by adoption rather than adaptation.

\section{References}

[1] Chukwuma, E. M., (2015), Human Resource Management Challenges In Nigeria Under A Globalized Economy: A Study Of Innoson Vehicles Manufacturing Company Nigeria Limited, Journal of Policy and Development Studies Vol. 9, No. 4, pp. 32-56 www.arabianjbmr.com/JPDS_index.php.

[2] Armstrong, M. (2009). Hand book of human resource management practice, London and Philadelphi: Kogan Print.

[3] Ameh, O. J., \& Daniel, E. I., (2017), Human Resource Management in the Nigerian Construction Firms: Practices and Challenges, Journal of Construction Business and Management, University of Cape Town, Vol. 2, No. 1, pp. 4653.
[4] Burton, L. (2003). The Next Big Thing, People Dynamics, Vol. 21, No. 2, pp. 23-31.

[5] Kane, B. (2001). Human resource management and trends in management; Travelling a well-worn path? New Zealand; Auckland paper presented to 15th Annual ANZAM Conference 6-8, Dec.

[6] Samwel, J. O., (2018) An Assessment of the Challenges Facing Recruitment, Selection and Retention Process in Small Industries in Mwanza Region" International Journal of Business and Management Invention (IJBMI), vol. 07, no. 03, pp. 35-41.

[7] Iguisi, O., (2014) African Values for the Practice of Human Resource Management, Beykent University Journal of Social Sciences, Vol, 7, No. 1, pp. 56-77.

[8] Marsden, T., (2019) Human Resource Management Challenges, https://www.villanovau.com/resources/hr/humanresource-management-challenges/Accessed 29/06/2019.

[9] Holwerda, J. (2014). Global applicability of human resource practices. Retrieved on June 10, 2014 from https://www.ilr.cornell.edu\%2Fcahrs\%2Fresearch\%2Fwhitepa pers $\% 2$ Fupload\%2FGlobalApplicability_HRPractices.pdf.

[10] Msiska, R., (2015), Challenges of human resource management in the African public service, http://africapolicyreview.com/challenges-of-human-resourcemanagement-in-the-african-public-service/ accessed 18/11/2019.

[11] Jovanovich, D. M. (2004). Research, Evaluation, Planning and Assessment Experience. John Tyler Community College, Midlothian, Virginia. Kalimullah, A. R., Yagoubi, N. M., \& Moloudi, J. (2010). Survey of relationship between organizational justice and empowerment. A case study. European Journal of Economics, Finance and Administrative Sciences, 24, 165-171.

[12] Opatha, H. H. D. N. P. (2010). Human resource management. Colombo: Author published. Pilbeam, S., \& Corbridge, M. (2006). People Resourcing. Contemporary Human Resource Management in Practice. London. Prentice Hall.

[13] Ofori, D., \& Aryeetey, M. (2011). Recruitment and selection practices in small and medium enterprises. International Journal of Business Administration, Vol. 2, No. 3, pp. 45-60.

[14] Bratton, J., \& Gold, J. (2007). Reward management. In: J. Bratton \& J. Gold (Eds.). America"s Best-Run Companies, HarperCollins Publishers, London.

[15] Costello, D., (2006), Leveraging the Employee Life Cycle, CRM Magazine, Vol. 10, No. 12, p 48.

[16] Mondy, R. W. (2010). Human Resource Management, 11th Edition. Upper Saddle River, New Jersey: Prentice Hall.

[17] Mathis, R. L., \& Jackson, J. H. (2006). Human Resource Management, 11th Edition, Thomson South-Western, USA, p 24.

[18] Gamage, A. S. (2014). Recruitment and selection practices in manufacturing SMEs in Japan: An analysis of the link with business performance. Ruhuna Journal of Management and Finance, Vol. 1, No. 1, pp. 37-52.

[19] Matheson, C., (2007), In Praise of Bureaucracy? A Dissent from Australia, Administration and Society, e-journal, Vol. 39, No. 2, pp. 233-261. 
[20] Okpara, J. O., \& Wynn, P., (2008) Human Resource Management Practices in a transition Economy, Emerald, Management Research News, Vol. 31, No. 1, pp. 57-76. 